
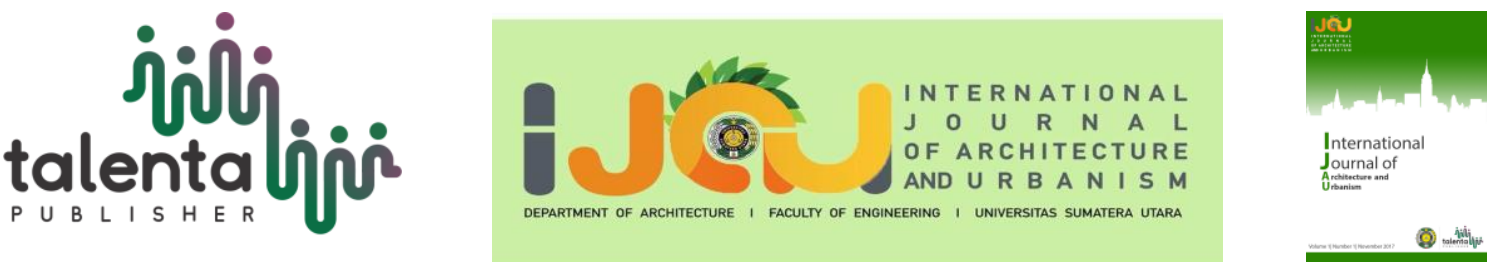

\title{
Study of Thermal Comfort in Traditional House Buildings (Case Study: Simalungun Traditional House)
}

\author{
Vinky Rahman ${ }^{1 *}$, Luqman Hadi Wibowo ${ }^{I}$ \\ ${ }^{1}$ Architecture Department, Faculty of Engineering, University of North Sumatra, Medan, Indonesia
}

\begin{abstract}
Traditional houses were formed over a long period and are believed to be hereditary responsive to the surrounding physical and socio-cultural environment. Traditional Architecture is a building whose shape, decoration and method of implementation are passed down from generation to generation. Traditional architecture is a reflection of the values and culture that the community has interpreted. The adaptation of residents in the house is carried out by optimizing the positive potential of the surrounding environment and minimizing disturbances related to the comfort of living. The research problem is how the level of thermal comfort in the traditional house of Simalungun. The purpose of this study is to analyze the thermal comfort of the study object of the Simalungun traditional house. To determine the thermal conditions inside and outside the building, Measurements of temperature and humidity were carried out. Measurement data were analyzed and compared with Ecotech simulation data. The results of research carried out directly and simulating using Ecotech. This Simalungun traditional house can be categorized as having optimal comfort in terms of its physical physiological aspects and simulate using Ecotech simulations. As for the benefits of the research, it is hoped that it can provide knowledge about the thermal comfort of traditional houses, especially the traditional houses of Simalungun.
\end{abstract}

Keyword: ecotech, Simalungun, thermal, traditional house

Received 14-1-2021 | Revised 20-1-2021 | Accepted 26-1-2021

\section{$1 \quad$ Introduction}

Traditional houses were formed over a long period and are believed to be hereditary responsive to the surrounding physical and socio-cultural environment. Adaptation of residents in the house is made by optimizing the positive potential of the surrounding environment and minimizing disturbances related to comfort in living. Research on the comparison of the advantages of traditional houses with modern houses has been made. Passive design to achieve thermal comfort in buildings can refer to the passive design system found in traditional houses because it has better thermal performance compared to modern houses [1].

\footnotetext{
*Corresponding author at: Architecture Department, Faculity Of Enginering, Universitas Sumatera Utara, Street Perpustakaan Gedung Medan 20155, Indonesia

E-mail address: vinkyrahman@gmail.com
} 
Other research shows that traditional houses in tropical countries are more sensitive to the prevailing climate and can provide a comfortable internal environment for residents [2]. The comfort of residents in the house is determined by a combination of several passive control strategies. Thermal temperature, which is the result of a comprehensive knowledge of climatic conditions [3]. A comparative study for evaluating thermal performance is made basis on differences in temperature in the house with the temperature in the outside environment. Evaluation comfort conditions is based on an analysis of temperature and relative humidity [4]. Retrieval of thermal data in one-year climate cycle through measurements field becomes a constraint because it requires cost, competence, equipment and time. However, the measurement method in the field for 24 hours with an interval of one hour is sufficient to describe local climate phenomena [5].

\section{Literature Review}

Traditional architecture

Traditional architecture is a form of architecture that is passed down from one generation to the next. Studying traditional building means studying community traditions that are more than just traditions physical building traditions. Traditional society is bound by custom, which is the concession in living together [6]. Traditional architecture is a building whose form, structure, function, decoration and method of manufacture are passed down from generation to generation and can be used carry out life activities as well as possible [7]. Traditional architecture is cultural identity of an ethnic group, because it contains all the life of its people [8].

Traditional house

A traditional house is a house that is built in the same way from generation to generation and has experienced little or no change. A traditional house can also be said to be a house built with due regard to the use, social function and cultural meaning behind the style or style. Assessment of the category of traditional houses can also be seen from the habits of the community when the house is an expression of the from of house-made by humans which is one of the elements of culture that grows or develops simultaneously with the development of culture in society. Architectural decorations in traditional houses are inseparable. The traditional house is a crucial component of the physical elements that reflect the culture and tendency of cultural traits are formed from traditions in society [9].

\section{Thermal Comfort}

Comfort consists of Physical a comfort and non-physical comfort. physical environment comfort is comfort that can be measured objectively (quantitatively) while non-physical comfort is psychological comfort (feeling of safety, quiet, happy, and others) subjectively measured (qualitative). Thermal comfort is a condition in which psychologically, physiologically, and behaviour patterns a person feels comfortable to carry out activities with a specific temperature 
in an environment. In theory, humans can adapt to thermal changes which are divided into three categories, namely adaptation to behaviour patterns, physiological adaptations and psychological adaptations [10].

Several studies have shown that the limit of comfort (in Effective Temperature / TE) varies depending on the geographical location and human subjects (ethnic groups) [11] studied as in Table 1:

Table 1 Comfort limit (in Effective Temperature / TE)

\begin{tabular}{llll}
\hline Author & The place & Human Group & Limits of Comfort \\
\hline ASHRAE & South USA $\left(30^{\circ} \mathrm{N}\right)$ & Indian researchers & $20.5^{\circ} \mathrm{C}-24.5^{\circ} \mathrm{C} \mathrm{TE}$ \\
Rao & Calcutta $\left(22^{\circ} \mathrm{N}\right.$ & Malaysia & $20^{\circ} \mathrm{C}-24.5^{\circ} \mathrm{C} \mathrm{TE}$ \\
& Equatorial Singapore & China & $25^{\circ} \mathrm{C}-27^{\circ} \mathrm{C} \mathrm{TE}$ \\
Webb & Jakarta $\left(6^{\circ} \mathrm{S}\right)$ & Indonesia & $20^{\circ} \mathrm{C}-26^{\circ} \mathrm{C} \mathrm{TE}$ \\
Mom & Equatorial Singapore & Europe & $22^{\circ} \mathrm{C}-26^{\circ} \mathrm{C} \mathrm{TE}$ \\
\hline
\end{tabular}

A state of mind expresses a person's level of satisfaction with this thermal environment as a definition of comfort [12]. The term the physical state of body is better than the physical state of the environment and what we really feel is skin temperature and not air temperature as a definition of thermal comfort [13]. Thermal comfort includes air temperature, air humidity, and airflow velocity. Thermal comfort in humid tropics can be achieved with limits of $24^{\circ} \mathrm{C}<\mathrm{T}$ $<26^{\circ} \mathrm{C}, 40 \%<\mathrm{RH}<60 \%, 0.6<\mathrm{V}<1.5 \mathrm{~m} / \mathrm{s}$. If the air temperature around the human body is higher than normal body temperature $\left(37^{\circ} \mathrm{C}\right)$, the blood flow in the limbs will increase the skin temperature so that the process of releasing heat in the body by radiation to the air will occur, and the body will sweat [14].

Three thermal comfort standards for humidity are used relative humidity is $20-50 \%$. The healthy air humidity is $40 \%-60 \%$. The area of thermal comfort in conditioned buildings for Indonesians is $40 \%-70 \%$. The standard used in this study is the standard of thermal comfort with the highest temperature of $27.1^{\circ} \mathrm{C}$ and humidity of $50-60 \%$. According to Lippsmeier (1994), at a sufficient temperature of $26{ }^{\circ} \mathrm{C}$, humans begin to sweat, at a temperature of $27.1{ }^{\circ} \mathrm{C}$ - $30{ }^{\circ} \mathrm{C}$ TE the human body remembers and the ability to work begins to decline. Temperature $30{ }^{\circ} \mathrm{C}-33.5^{\circ} \mathrm{C}$ TE environmental conditions are difficult to adjust to body conditions.

\section{Ventilation}

Ventilation is the process of supplying conditioned air into the room and removing the air out from various methods. Adequate ventilation provides a continuous change of air in the room. The air that changes regularly can improve occupant comfort. The importance of air movement 
and replacing dirty air with clean air is also an environmental conditioning action that has a significant impact on thermal comfort [15].

\section{Methodology}

The method used in this research is a quantitative methods approach. Data collection was carried out after the location and research object was determined based on criteria. Data were collected utilizing observation, measurement and shooting techniques. In this study the data were taken based on the origin of the data, namely: Data on the results of measurements of room temperature and humidity at different times, building designs including building orientation, sun shading, building physical size data (draft, floor plan, situation, appearance, cut, detailed specifications technical data from the research object), geographic data of the object, climate data from the BMKG. In this study, direct location measurements were made of temperature and humidity at two points, outer space and inner space.

The measuring point is in the middle of the front room and the other one is outside the building. Measurements were made with a thermometer and hydrometer. The object selected is a traditional house simalungun where the object is one of the traditional buildings in North Sumatra. The location of this Simalungun traditional house is in the town of Pematang Purba, Simalungun Regency, North Sumatra. The location of the measurements inside and outside the room ( Figure 1 and 2 ).

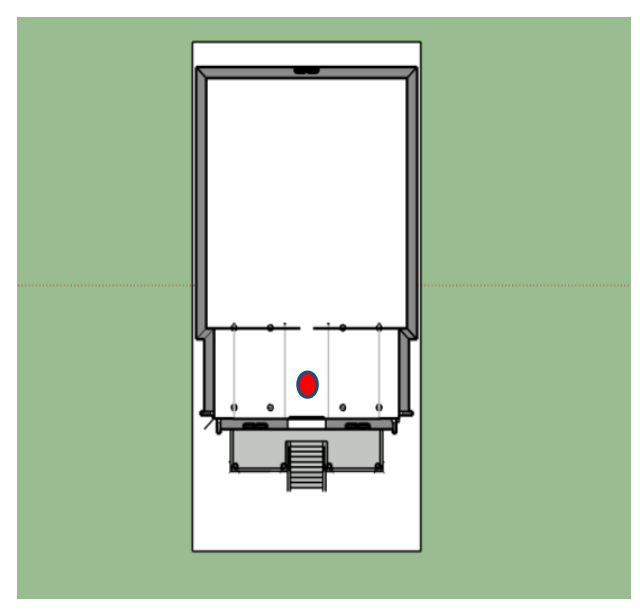

Figure 1 Location of measurement points in space in 


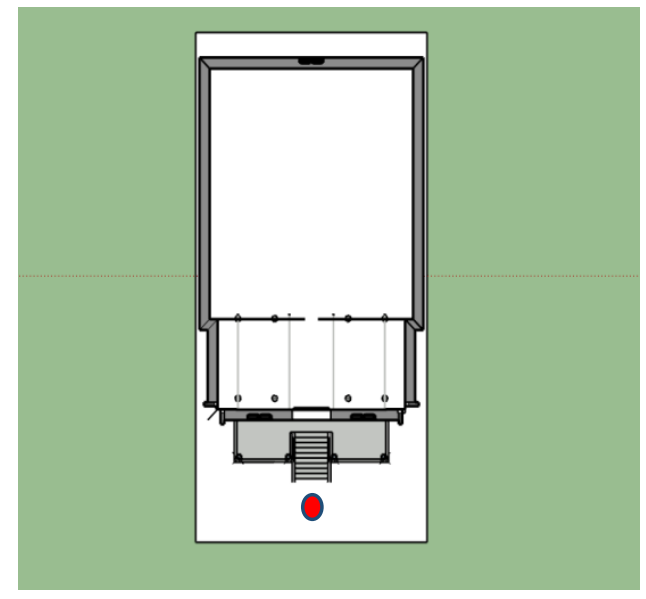

Figure 2 Location of measurement points outside the room

\section{$4 \quad$ Result and Discussion}

The traditional house for the Batak people is established not only as a place to shade and take shelter from rain and hot sun but is full of philosophical values that can be used as a guide for life. Various definitions and noble values that are inherent and contained in traditional houses should be interpreted and held as a view of life in the order of everyday life, in the context of an interaction between individuals.

The results of the overall measurement of thermal conditions (temperature and humidity) inside and outside the traditional house can seen in Table 2.

Table 2 The temperature and humidity of the whole day in the traditional house

\begin{tabular}{cccccc}
\hline \multirow{2}{*}{ Day } & & \multicolumn{2}{c}{ Inner space } & \multicolumn{2}{c}{ Outdoor } \\
\cline { 3 - 6 } & Information & Temperature & RH & Temperature & RH \\
$(\mathbf{( \% )}$ & ( $)$ & C) & $(\%)$ \\
\hline \multirow{3}{*}{ Day 1 } & Min & 22.00 & 70.00 & 20.00 & 70.00 \\
& Max & 23.00 & 80.00 & 22.00 & 85.00 \\
& Average & 22.50 & 76.00 & 21.00 & 77.50 \\
Day 2 & Min & 23.00 & 65.00 & 22.00 & 65.00 \\
& Max & 25.00 & 75.00 & 26.00 & 75.00 \\
& Average & 24.00 & 70.00 & 24.00 & 70.00 \\
Day 3 & Min & 22.00 & 65.00 & 22.00 & 70.00 \\
& Max & 25.00 & 85.00 & 28.00 & 85.00 \\
& Average & 23.00 & 75.00 & 25.00 & 75.00 \\
Day 4 & Min & 22.00 & 65.00 & 23.00 & 60.00 \\
& Max & 26.00 & 80.00 & 28.00 & 75.00 \\
& Average & 24.50 & 75.00 & 26.00 & 70.00 \\
\hline
\end{tabular}

From all the measurements made directly using a thermohydrometer, the overall data is obtained as shown in the table above. Of all the days, none experienced a very significant difference and all temperatures and humidity were in optimal comfortable comfort conditions according to [11] theory which was at $22.8{ }^{\circ} \mathrm{C}-25.8{ }^{\circ} \mathrm{C}$ (TE) for air temperature, and $70 \%-80 \%$ relative humidity for humidity. 
Measurement Results by Simulation of the Thermal Conditions of Traditional Houses. Based on the Ecotech simulation by making a model of the traditional Simalungun house in Pematang Purba city, Simalungun Regency shown in Figure 3.

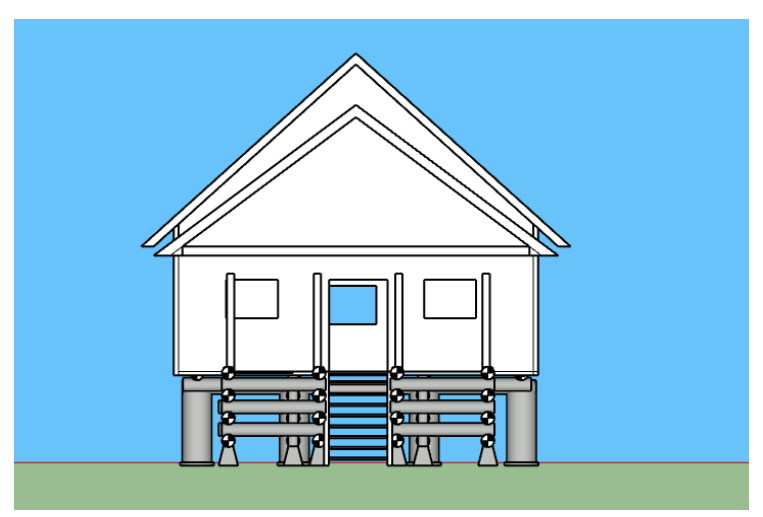

Figure 3 Traditional House Design

The following are the simulation results on day 1 to day 4 using Ecotech simulation shown in, Figure 4-7.

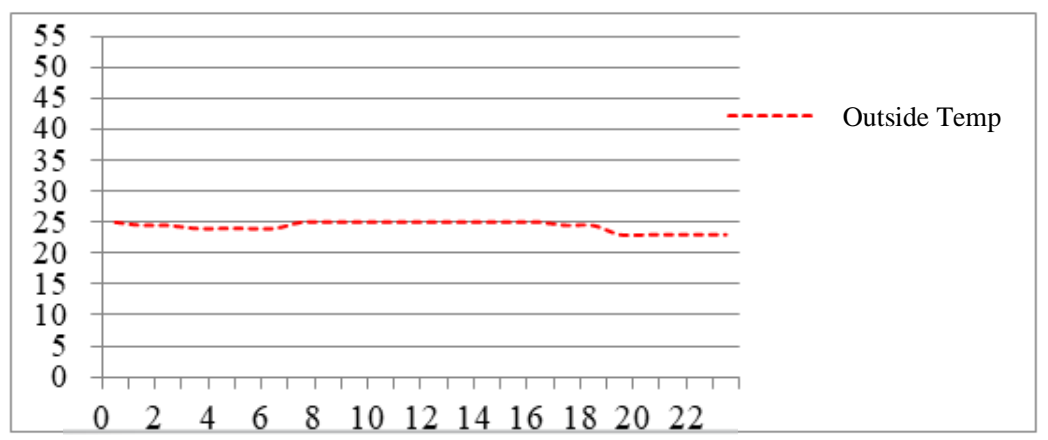

Figure 4 Simulation Results for Day 1

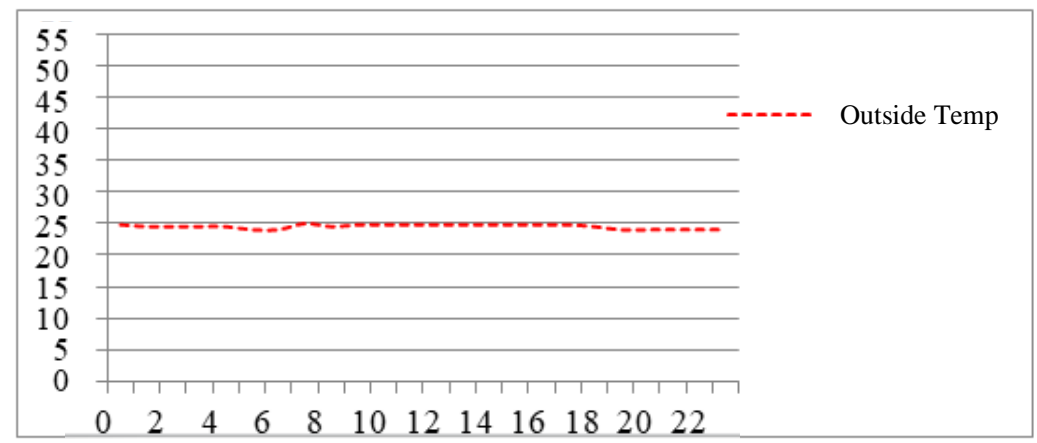

Figure 5 Simulation Results for Day 2 


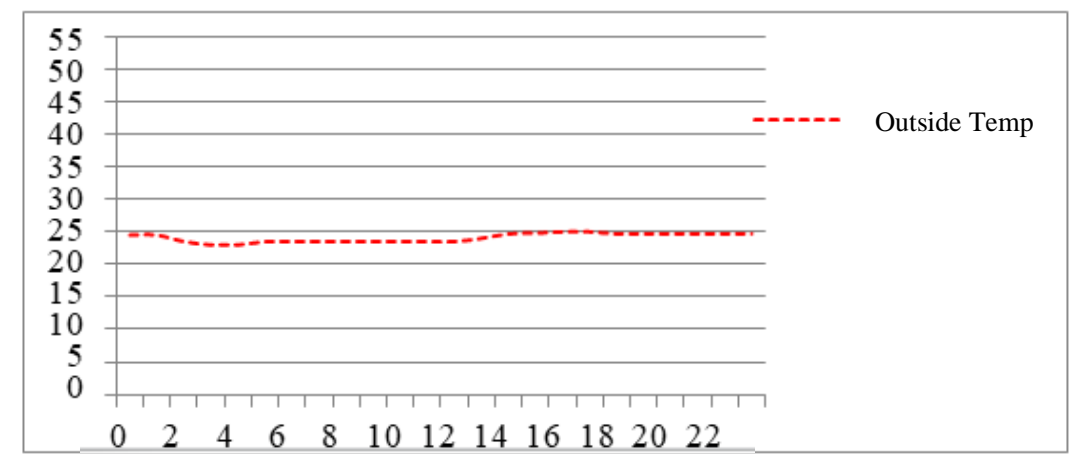

Figure 6 Simulation Results for Day 3

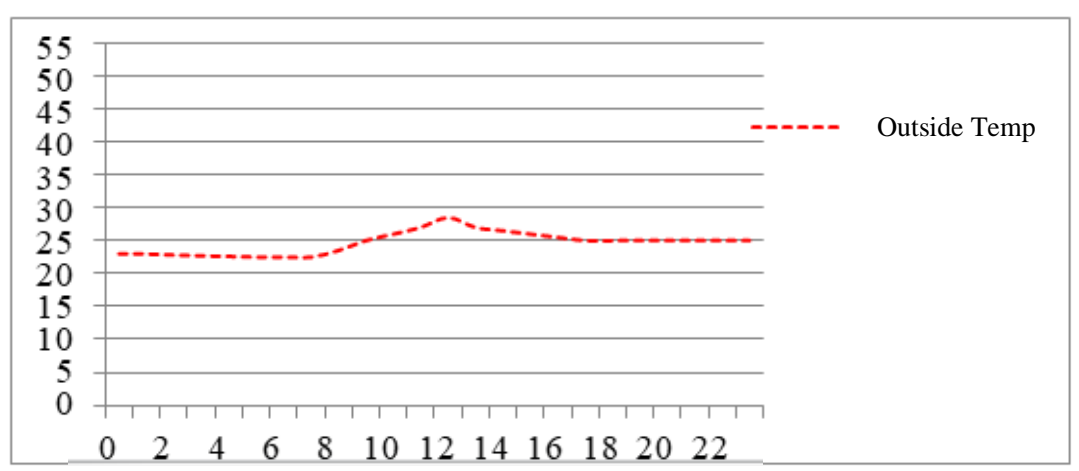

Figure 7 Simulation Results Day 4

From the results of the 1th-4th day Ecotech simulation above, the temperature data from the Simalungun traditional house shows that the maximum temperature conditions touch a temperature of $26.50^{\circ} \mathrm{C}$. The minimum temperature of the house touches $23^{\circ} \mathrm{C}$ and the average temperature is at $25{ }^{\circ} \mathrm{C}$ with the humidity inputted. by $60 \%-80 \%$. So based on the simulation results above based on [11] standard of thermal comfort at an effective temperature of $26{ }^{\circ} \mathrm{C}$, humans start to sweat, at a temperature of $27.1^{\circ} \mathrm{C}-30^{\circ} \mathrm{C}$ TE the human body sweats and the ability to work starts to decline and can be said to be in the comfortable category, $22.8^{\circ} \mathrm{C}-25.8$ ${ }^{\circ} \mathrm{C}(\mathrm{TE})$.

A Comparison of Direct Measurement Results and Simulation Ecotech. The results of measurements of thermal conditions (temperature and humidity) inside and outside the traditional house can be seen Table 3 . 
Table 3 The results of comparison of simulations and direct measurements

\begin{tabular}{|c|c|c|c|c|c|}
\hline & & \multicolumn{2}{|c|}{ Direct measurement } & \multicolumn{2}{|c|}{ Ecotech Simulation } \\
\hline & & $\begin{array}{c}\text { Temperature } \\
\left({ }^{\circ} \mathbf{C}\right)\end{array}$ & $\begin{array}{l}\mathrm{RH} \\
(\%)\end{array}$ & $\begin{array}{c}\text { Temperature } \\
\text { ('C) }\end{array}$ & $\begin{array}{l}\mathrm{RH} \\
(\boldsymbol{\%})\end{array}$ \\
\hline \multirow[b]{2}{*}{ Day 1} & Min & 22.00 & 70.00 & 23.00 & 75.00 \\
\hline & $\begin{array}{c}\text { Max } \\
\text { Average }\end{array}$ & $\begin{array}{l}23.00 \\
22.50\end{array}$ & $\begin{array}{l}80.00 \\
76.00\end{array}$ & $\begin{array}{l}25.00 \\
24.00\end{array}$ & $\begin{array}{l}85.00 \\
79.00\end{array}$ \\
\hline \multirow[b]{2}{*}{ Day 2} & Min & 23.00 & 65.00 & 24.00 & 70.00 \\
\hline & $\begin{array}{c}\text { Max } \\
\text { Average }\end{array}$ & $\begin{array}{l}25.00 \\
24.00\end{array}$ & $\begin{array}{l}75.00 \\
70.00\end{array}$ & $\begin{array}{l}25.50 \\
24.00\end{array}$ & $\begin{array}{l}80.00 \\
75.00\end{array}$ \\
\hline \multirow[b]{2}{*}{ Day 3} & Min & 22.00 & 65.00 & 23.00 & 75.00 \\
\hline & $\begin{array}{c}\text { Max } \\
\text { Average }\end{array}$ & $\begin{array}{l}25.00 \\
23.00\end{array}$ & $\begin{array}{l}85.00 \\
75.00\end{array}$ & $\begin{array}{l}25.00 \\
24.00\end{array}$ & $\begin{array}{l}85.00 \\
77.00\end{array}$ \\
\hline \multirow{2}{*}{ Day 4} & Min & 22.00 & 65.00 & 23.00 & 65.00 \\
\hline & $\begin{array}{c}\text { Max } \\
\text { Average }\end{array}$ & $\begin{array}{l}26.00 \\
24.50 \\
\end{array}$ & $\begin{array}{l}80.00 \\
75.00 \\
\end{array}$ & $\begin{array}{l}26.50 \\
25.00 \\
\end{array}$ & $\begin{array}{l}80.00 \\
74.00 \\
\end{array}$ \\
\hline
\end{tabular}

Seen in the table above, the average air temperature based on direct measurements and Ecotech simulations does not have a significant difference. Direct measurement of air temperature and air temperature generated by simulating using Ecotech only experienced a difference of $1{ }^{\circ} \mathrm{C}-3$ ${ }^{\circ} \mathrm{C}$ higher. Windows/ventilation is an essential factor in creating a comfortable temperature and humidity in a building, the calculation results of the simulation experience a higher temperature and higher humidity due to the simulation of openings such as windows and doors being one of the factors that cause humidity and temperature at the building gets higher results than the direct measurement, and with simulations that do not take into account changes in weather that occur suddenly at the same time. However, from these results it can be said that the simulation and direct measurement can still be said that the thermal comfort in terms of physical physiological aspects can still be said to be in the category of optimal comfort.

\section{Conclusion}

Based on the results of research conducted directly and simulating using Ecotech, this traditional Simalungun house can be categorized as having optimal comfort in terms of its physical physiological aspects. The results of the research were at the location of the Simalungun traditional house in Pematang Purba city, Simalungun Regency. Shows that the maximum temperature and humidity outside the building is higher than inside the traditional house building. The air temperature inside the building is $22.00{ }^{\circ} \mathrm{C}-26.00{ }^{\circ} \mathrm{C}$ with humidity in the range of $65 \%-85 \%$. The air temperature outside the building is in the range $20.00^{\circ} \mathrm{C}$ $28.00^{\circ} \mathrm{C}$ with humidity in the range of $65 \%-85 \%$. Until now, there is no standard can be used as a reference for thermal comfort limits for traditional house buildings in Indonesia. In this research, a study [11] can be used as a reference for assessing the limit of thermal comfort for this traditional house building. [11] stated that at a sufficient temperature of $26{ }^{\circ} \mathrm{C}$, humans 
began to sweat, at a temperature of $27.1^{\circ} \mathrm{C}-30{ }^{\circ} \mathrm{C}$ TE the human body remembered. The ability to work began to decline. Furthermore ventilation is one of the factors that can change humidity and temperature in buildings.

\section{Acknowledgement}

This research is about the thermal comfort of traditional houses, especially the Traditional Simalungun house. The author thanks the Department of Architecture at North Sumatra University for the guidance in writing this research.

\section{REFERENCES}

[1] Kubota, T and Toe, D.H.C, "Local Wisdom In Malaysian Vernacular Architecture : Comparison Of Thermal and Modern Houses," Proceedings of the 12 th International Conference on Sustainable Environment and Architecture (SENVAR), no. 1-9.

[2] Fitriaty P, Antaryama IGN, Sri- Nastiti NE, "Thermal Performance Of Traditional House In the Upland Central Celebes, Indonesia," IPTEK- The Journal For Technology and Science, Vols. 22, No 4, 2011.

[3] Khoukhi, M., \& Fezzioui, N., "Thermal comfort design of traditional houses in hot dry region of Algeria," International Journal of Energy and Environmental Engineering, vol. 3(1), pp. 1-9, (2012).

[4] Rumana, Rashid, and Mohd Hamdan Bin Ahmed, "The Comparison Between the Thermal Performance of a Contemporary House and Traditional House in The Dense Dhaka City in Bangladesh," DIMENSI (Jurnal Teknik Arsitektur), vol. 40, pp. 11-18, 2013.

[5] Prasetyo, Yuri Hermawan, Eksplorasi Arsitektur Sumatra, Edisi : Etnis Batak Toba, PT. Raja Grafikindo Persada, 2014.

[6] R. Amos, House Form and Culture, New Delhi: Prentice-Hall Of India Private Ltd, 1969.

[7] E. Budihardjo, Jati Diri Arsitektur Indonesia, Bandung: Alumni, 1997.

[8] T. B. Usop, "Kearifan lokal dalam arsitektur kalimantan tengah yang berkesinambungan," Jurnal Perspektif Arsitektur, vol. 6(01), pp. 25-32, (2011).

[9] S. V. Szokolay, Introduction to Architectural Science : The Basis Of Sustainable Design, Elsevier S.A, 2002.

[10] R. W. Berman, Assesing Urban Design: Historical Ambience on The Waterfront, Lexington Books, 2006.

[11] G. Lippsmeier, "Tropenbau Building in the Tropics: Bangunan Tropis," Jakarta (ID): Erlangga, 1994.

[12] S. Sugini, "Pemaknaan Istilah-Istilah Kualitas Kenyamanan Thermal Ruang Dalam Kaitan Dengan Variabel Iklim Ruang.," Jurnal Logika, vol. 1(2), 2004.

[13] P. Fanger, "Thermal comfort. Analysis and Applications in Environmental Engineering," Robert E. Krieger Publishing Company, 1982. 
[14] P. Satwiko, "Fisika Bangunan (Yogyakarta: Penerbit Andi)," 2008.

[15] B. T.S, Controlling Air Movement : Builder, New York: McGraw-Hill Book Comp, 1987. 